\title{
Design and Synthesis of New Dioxa Diazaspiro[bicyclo [9.4.2] Heptadecane-Steroid-Dienyne Derivative from Estrone and OTBS-estrone
}

\author{
LÓPEZ-RAMOS MARIA ${ }^{1}$, FIGUEROA-VALVERDE LAURO ${ }^{1 *}$, ROSAS-NEXTICAPA MARCELA ${ }^{3}$, \\ HERRERA-MEZA MARIA DEL SOCORRO ${ }^{4}$, CERVANTES-ORTEGA CATALINA ${ }^{3}$, \\ DÍAZ-CEDILLO FRANCISCO², GARCÍA-CERVERA ELODIA ${ }^{1}$ and POOL-GÓMEZ EDUARDO'
}

'Laboratory of Investigation, Faculty Chemical-Biological Sciences; University Autonomous

of Campeche. Agustin Megar s/n, Bellavista C.P. 24039, Campeche Mexico.

${ }^{2}$ Escuela Nacional de Ciencias Biológicas del Instituto Politécnico Nacional. Prol.

Carpio y Plan de Ayala s/n Col. Santo Tomas, México, D.F. C.P. 11340.

${ }^{3}$ Facultad de Nutrición, Universidad Veracruzana. Médicos y Odontólogos s/n,

91010, Xalapa Veracruz, México.

${ }^{4}$ Instituto de Investigaciones Psicológicas. Universidad Veracruzana. Av. Dr Luis Castelazo

$\mathrm{S} / \mathrm{N}$ Col. Industrial Animas Xalapa Veracruz, Mexico.

${ }^{*}$ Corresponding author E-mail: lauro_1999@ yahoo.com

http://dx.doi.org/10.13005/ojc/330301

(Received: November 10, 2017; Accepted: February 05, 2017)

ABSTRACT

Several bicycle-derivatives have been prepared using different protocols; nevertheless, expensive reagents and special conditions are required. The aim of this study was synthesize a dioxa-diazaspiro[bicyclo[9.4.2] heptadecane-steroid-dienyne derivative by a series of reactions which involving; a) alkinilization of estrone or OTBS-estrone with 5-hexyn-1-ol to form two propargyl alcohol derivatives ( 3 or 4 ); b) esterification 3 or 4 with succinic acid to form two dioxaspiro-steroidcyclotridecan derivatives (5 or 6); c) preparation of diazaspiro[bicycle[9.4.2] heptadecane-steroid-4 amino complex ( 7 or 8 ) by reaction of 5 or 6 with ethylenediamine; d) removal of silyl fragment of 8 via hydrofluoric acid to form the compound diazaspiro[bicycle[9.4.2] heptadecane-steroid-3'-ol (9); e) preparation of diazaspiro[bicycle[9.4.2] heptadecane-steroid-4-oxobutanoic acid (10) via esterification of 9 with succinic acid; f) amidation of 10 with ethylenediamine to form diazaspiro[bicyclo[9.4.2] heptadecane-steroid-4-aminobutanoate (11); g) synthesis of dioxadiazaspiro [bicyclo[9.4.2] heptadecane-steroid-dienyne (12) via pyrrolization of 11 using boric acid. The chemical structure of compounds was confirmed by NMR spectroscopic data.

Keywords: OTB-estrone, Chemical synthesis.

\section{INTRODUCTION}

Since several years ago, have been prepared several bicylo-derivatives which represent a very interesting class of compounds that have attracted the attention of many organic chemists. For example, the synthesis of 1,3-diace- tylbicyclo[I.I.I] pentane by the reaction of 1,1-dibromo-2,2- 
bis(chloromethyl)cyclopropane and methyllithium ${ }^{1}$. Other study, showed the selenium-mediated cyclization of alkenyl-substituted $\alpha$-dicarbonyls (I) to form a variety of bicyclo[3.3.1]nonan-9-ones both in solution and on solid support ${ }^{2}$. In addition, other report indicated the preparation of an azabicyclo[2.2.I] heptane derivative by the reaction of N-Benzyl5-[1'-(methoxycarbony1)-3'-oxobutyl] proline with oxalyl chloride-1,2-dichloro- ethane ${ }^{3}$. Also, a study showed the reaction of $(E)$-Hex-3-ene-1,6-dithiol with $\mathrm{p}$-anisaldehyde to form an azathia-bicycle derivative ${ }^{4}$. Other data showed the coupling of cinnamaldehyde to $(E)$-hex-3-ene-1,6-ditosylamide in the presence of $\mathrm{Sc}(\mathrm{OTf})_{3}$ to form trans-fused octahydropyrrolo[3,2-c] pyridine ${ }^{5}$. Additionally, a study shown the preparation of bicycle [3.2.1]octan-8-one by the reaction of 1,2-cyclohexanedione with $\alpha$-nitros-tyrene ${ }^{6}$. Other report indicate the preparation of 9-(Phenylthio) bicyclo[3.2.2]nona-3,6-dien-2-one by reaction of 2,4,6-cycloheptatrien-l-one with phenyl vinyl sulfide ${ }^{7}$. In addition, a study indicated the synthesis of 7,7dichloro-cis-bicyclo[4.2.0]octan-8-one by reaction of cyclo- hexene with trichloroacetyl bromide/copper(II) sulfate $^{8}$. All these experimental results show several procedures which are available for synthesis of diverse bicycle derivatives; nevertheless, expensive reagents and special conditions are required. Therefore, in this study a diazaspiro[bicyclo[9.4.2] heptadecane derivative from estrone and OTBSestrone (Scheme 1) was synthetized using some chemical tools. It is noteworthy that this compound could be used in some biological model to evaluate their pharmacological activity for therapeutic purposes.

\section{MATERIAL AN METHODS}

\section{General methods}

The OTB-estrone (3-(Tert-butyl-dimethylsilanyloxy)-13-methyl-6,7,8,9,11,12,13,14,15, 16decahydro-cyclopenta[a] phenanthren-17-one) was prepared by a method previously reported ${ }^{9}$. The others reagents used in this study were purchased from Sigma-Aldrich Co. Ltd. The melting point was determined on an Electrothermal (900 model). Infrared spectra (IR) were recorded using $\mathrm{KBr}$ pellets on a Perkin Elmer Lambda 40 spectrometer. ${ }^{1} \mathrm{H}$ and ${ }^{13} \mathrm{C}$ NMR spectra were recorded on a Varian VXR300/5 FT NMR spectrometer at 300 and 75.4 MHz in $\mathrm{CDCl}_{3}$ using TMS as internal standard. EIMS spectra were obtained with a Finnigan Trace GCPolaris Q. spectrometer. Elementary analysis data were acquired from a Perkin Elmer Ser. II CHNS/0 2400 elemental analyzer.

\section{Chemical synthesis \\ Preparation of two propargyl alcohol derivatives (3 or 4)}

A mixture of estrone or OTBS-estrone $(0.50$ mmol), 5-hexyn-1-ol (60 $\mu \mathrm{l}, 0.54 \mathrm{mmol})$, potassium hydroxide (30 mg, $0.53 \mathrm{mmol})$, in $5 \mathrm{ml}$ of methanol was stirring for $72 \mathrm{~h}$ to room temperature. The reaction mixture was evaporated to dryness under reduced pressure. After, the residue was purified by crystallization from methanol:water (4:1)

17 - (6-Hydroxy-hex - 1 - ynyl)- 13 - methyl$7,8,9,11,12,13,14,15,16,17-d e c a h y d r o-6 \mathrm{H}-c y c l o$ penta[a]phenanthrene-3,17-diol (3).

yielding $55 \%$ of product, m.p. $182-184^{\circ} \mathrm{C}$; $\mathrm{IR}\left(\mathrm{V}_{\max }, \mathrm{cm}^{-1}\right): 3400$ and 2192; ${ }^{1} \mathrm{H}$ NMR $(300 \mathrm{MHz}$, $\left.\mathrm{CDCl}_{3}\right) \delta_{\mathrm{H}}: 0.92(\mathrm{~s}, 3 \mathrm{H}), 1.22-1.50(\mathrm{~m}, 4 \mathrm{H}), 1.58-1.60$ $(\mathrm{m}, 4 \mathrm{H}), 1.70-2.10(\mathrm{~m}, 6 \mathrm{H}), 2.20(\mathrm{t}, 2 \mathrm{H}, \mathrm{J}=13.47 \mathrm{~Hz})$, 2.24- $2.76(\mathrm{~m}, 5 \mathrm{H}), 3.66(\mathrm{t}, 2 \mathrm{H}, \mathrm{J}=11.00 \mathrm{~Hz}), 5.54$ (broad, 3H), 6.48-7.10 (m, 3H) ppm. ${ }^{13} \mathrm{C}$ NMR (75.4 $\left.\mathrm{Hz}, \mathrm{CDCl}_{3}\right) \delta_{\mathrm{C}}: 12.28,18.90,23.66,25.54,26.92$, $27.70,30.30,31.82,34.90,36.62,37.87,44.89$, $48.12,52.80,62.12,80.10,80.66,83.42,112.72$, 115.34, 126.5, 132.24, 138.34, 153.02 ppm. El-MS m/z: 368.23 Anal. Calcd. for $\mathrm{C}_{24} \mathrm{H}_{32} \mathrm{O}_{3}: \mathrm{C}, 78.22 ; \mathrm{H}$, 8.75; O, 13.02. Found: C, 78.16; H, 8.64.

3-(tert-Buthyl-dimethyl-silanyloxy)-17-(6Hydroxy-hex-1-ynyl)-13-methyl-7,8,9,11,12, $13,14,15,16,17$-decahydro-6H-cyclopenta[a] phenanthrene-17-ol (4).

yielding $66 \%$ of product, m.p. $176-178{ }^{\circ} \mathrm{C}$; IR $\left(\mathrm{V}_{\max }, \mathrm{cm}^{-1}\right): 3400,2198$ and 1098; ${ }^{1} \mathrm{H}$ NMR (300 $\left.\mathrm{MHz}, \mathrm{CDCl}_{3}\right) \delta_{\mathrm{H}}: 0.28$ (s. $\left.6 \mathrm{H}\right), 0.92(\mathrm{~s}, 3 \mathrm{H}), 1.04$ (s, $9 \mathrm{H}), 1.22-1.50(\mathrm{~m}, 4 \mathrm{H}), 1.58-1.60(\mathrm{~m}, 4 \mathrm{H}), 1.70-2.10$ $(\mathrm{m}, 6 \mathrm{H}), 2.20(\mathrm{t}, 2 \mathrm{H}, \mathrm{J}=13.47 \mathrm{~Hz}), 2.24-2.82(\mathrm{~m}$, $5 \mathrm{H}), 3.66$ (t, $2 \mathrm{H}, \mathrm{J}=11.00 \mathrm{~Hz}), 3.84$ (broad, $3 \mathrm{H})$, 6.84-7.28 (m, 3H) ppm. ${ }^{13} \mathrm{C} \mathrm{NMR}\left(75.4 \mathrm{~Hz}, \mathrm{CDCl}_{3}\right)$ $\delta_{\mathrm{C}}:-4.44,12.28,18.16,18.90,23.66,25.54,25.74$, $26.92,27.70,29.62,31.82,34.90,36.62,37.87$ $44.89,48.12,52.80,62.12,80.10,80.66,83.42$, 117.10, 119.94, 126.14, 132.64, 137.84, 153.32 ppm. El-MS m/z: 482.77 Anal. Calcd. for $\mathrm{C}_{30} \mathrm{H}_{46} \mathrm{O}_{3} \mathrm{Si}: \mathrm{C}$, 74.64; H, 9.60; O, 9.94 Found: C, 74.56; H, 9.52. 
Esterification 3 or 4 with succinic acid to form two dioxaspiro-steroid-cyclotridecan derivatives (5 or 6).

A solution of 5 or $6(0.5 \mathrm{mmol})$, succinic acid (100 $\mathrm{mg}, 0.85 \mathrm{mmol}), 1,3-$ dicyclohexylcarbodiimide (120 mg, $0.58 \mathrm{mmol}$ ), p-toluensulfonic acid monohydrate $260 \mathrm{mg}(1.36$ $\mathrm{mmol}$ ) in acetonitile:methanol $6 \mathrm{ml}$ (1:2) was stirring for $72 \mathrm{~h}$ to room temperature. The reaction mixture was evaporated to dryness under reduced pressure. After, the residue was purified by crystallization from methanol:water:hexane $(4: 2: 1)$

4 - ( ( ( $13 \mathrm{~S}$ ) - 13 - m e th y l - 2', 5 ' - d i ox o $6,7,8,9,11,12,13,14,15,16-d e c a h y d r o-1^{\prime}, 6^{\prime}-$ dioxaspiro [cyclopenta[a]phenanthrene-17,7'cyclotridecan]-8'-yn-3-yl)oxy)-4-oxobutanoic acid (5).

yielding $48 \%$ of product, m.p. $170-172{ }^{\circ} \mathrm{C}$; IR $\left(\mathrm{V}_{\max }, \mathrm{cm}^{-1}\right): 2194,1750$ and $1714 ;{ }^{1} \mathrm{H}$ NMR (300 $\left.\mathrm{MHz}, \mathrm{CDCl}_{3}\right) \delta_{\mathrm{H}}: 0.98(\mathrm{~s}, 3 \mathrm{H}), 1.08(\mathrm{~m}, 2 \mathrm{H}), 1.22-$ $1.44(\mathrm{~m}, 3 \mathrm{H}), 1.50(\mathrm{t}, 2 \mathrm{H}, \quad \mathrm{J}=6.45 \mathrm{~Hz}), 1.58-2.22$ $(\mathrm{m}, 8 \mathrm{H}), 2.24(\mathrm{t}, 2 \mathrm{H}, \mathrm{J}=14.40 \mathrm{~Hz}), 2.38-2.46(\mathrm{~m}$, $2 \mathrm{H}), 2.54-2.58(\mathrm{~m}, 4 \mathrm{H}), 2.60(\mathrm{t}, 2 \mathrm{H}, \mathrm{J}=16.00 \mathrm{~Hz})$, 2.68-2.76 (m, 2H), $2.90(\mathrm{~m}, 2 \mathrm{H}), 4.10(\mathrm{~m}, 2 \mathrm{H}), 6.78-$ 7.28 (m, 3H), 8.70 (broad, $1 \mathrm{H})$ ppm. ${ }^{13} \mathrm{C}$ NMR $(75.4$ $\left.\mathrm{Hz}, \mathrm{CDCl}_{3}\right) \delta_{\mathrm{C}}: 10.90,19.20,23.64,26.74,27.70$, $28.60,29.30,29.70,29.74,30.00,31.72,32.10$, $34.32,34.84,38.35,44.89,47.82,52.80,64.82$, 79.10, 80.99, 89.02, 119.50, 121.44, 126.64, 138.14, 139.44, 149.80, 171.30, 172.04, 173.70, 174.12 ppm. El-MS m/z: 550.25 Anal. Calcd. for $\mathrm{C}_{32} \mathrm{H}_{36} \mathrm{O}_{8}: \mathrm{C}$, 69.80; H, 6.96; O, 23.24. Found: C, 69.74; H, 6.87.

(13S)-3-((tert-butyldimethylsilyl)oxy)-13-methyl$6,7,8,9,11,12,13,14,15,16$-decahydro-1 ',6'dioxaspiro[cyclopenta [a]phenanthrene-17,7'cyclotridecan]-8'-yne-2',5'-dione (6).

yielding $64 \%$ of product, m.p. $160-162{ }^{\circ} \mathrm{C}$; IR $\left(\mathrm{V}_{\text {max }}, \mathrm{cm}^{-1}\right): 2196,1746$ and 1716; ${ }^{1} \mathrm{H}$ NMR (300 $\left.\mathrm{MHz}, \mathrm{CDCl}_{3}\right) \delta_{\mathrm{H}}: 0.28(\mathrm{~s}, 6 \mathrm{H}), 0.98(\mathrm{~s}, 3 \mathrm{H}), 1.08$ $(\mathrm{m}, 2 \mathrm{H}), 1.10(\mathrm{~s}, 9), 1.22-1.44(\mathrm{~m}, 3 \mathrm{H}), 1.50(\mathrm{t}, 2 \mathrm{H}, \mathrm{J}$ $=1.70 \mathrm{~Hz}), 1.58-2.22(\mathrm{~m}, 8 \mathrm{H}), 2.24(\mathrm{t}, 2 \mathrm{H}, \mathrm{J}=1.70$<smiles>CC12CCC3c4ccc(O)cc4CCC3C1CCC2=O</smiles><smiles>CC(C)(C)Oc1ccc2c(c1)CCC1C2CC[C@]2(C)C(=O)CCC12</smiles>

Scheme 1: Structure chemical of estrone and OTBS-estrone
$\mathrm{Hz})$, 2.38-2.46 (m, 2H), 2.54- $2.58(\mathrm{~m}, 4 \mathrm{H}), 2.80-2.82$ $(\mathrm{m}, 2 \mathrm{H}), 4.10(\mathrm{t}, 2 \mathrm{H}, \mathrm{J}=2.00 \mathrm{~Hz}), 6.84-7.28(\mathrm{~m}, 3 \mathrm{H})$ ppm. ${ }^{13} \mathrm{C}$ NMR $\left(75.4 \mathrm{~Hz}, \mathrm{CDCl}_{3}\right) \delta_{\mathrm{C}}:-4.44,10.90$, $18.16,19.20,23.66,25.72,26.74,27.70,28.60$, $29.60,30.00,31.72,32.10,34.32,34.84,38.36$, $44.89,47.82,52.80,64.82,79.10,80.99,89.02$, $117.20,119.94,126.14,133.40,137.74,153.42$, 172.04, 173.70 ppm. El-MS m/z: 564.32 Anal. Calcd. for $\mathrm{C}_{34} \mathrm{H}_{48} \mathrm{O}_{5} \mathrm{Si}: \mathrm{C}, 72.30 ; \mathrm{H}, 8.57 ; \mathrm{O}, 14.16$; $\mathrm{Si}, 4.97$. Found: C, 72.22; H, 8.48.

Preparation of diazaspiro[bicycle[9.4.2] heptadecane-steroid-4 amino complex (7 or 8) A solution of 5 or $6(0.5 \mathrm{mmol})$, ethylenediamine $(60 \mu \mathrm{l}, 0.90 \mathrm{mmol})$ boric acid $(60$ $\mathrm{mg}, 0.97 \mathrm{mmol}$ ) in $5 \mathrm{ml}$ of methanol was stirring for $72 \mathrm{~h}$ to room temperature. The reaction mixture was evaporated to dryness under reduced pressure. After, the residue was purified by crystallization from methanol:water (4:2)

( $\left.11 \mathrm{z}, 13^{\circ} \mathrm{s}\right)-13^{\prime}-\mathrm{m}$ e t $\mathrm{h}$ y I $6^{\prime}, 7^{\prime}, 8^{\prime}, 9^{\prime}, 11^{\prime}, 12^{\prime}, 13^{\prime}, 14^{\prime}, 15^{\prime}, 16^{\prime}$-decahydro2,10-dioxa-12,15-diazaspiro [bicycle[9.4.2] heptadecane-3,17'-[cyclopenta[a] phenanthrene] -1(15),11-dien-4-yn-3'-yl 4-amino-4-oxobutanoate (7)

yielding $56 \%$ of product, m.p. 186-188 ${ }^{\circ} \mathrm{C}$; IR $\left(\mathrm{V}_{\max }, \mathrm{cm}^{-1}\right): 3324,2194,1748$ and 1632; ${ }^{1} \mathrm{H}$ NMR $\left(300 \mathrm{MHz}, \mathrm{CDCl}_{3}\right) \delta_{\mathrm{H}}: 0.98(\mathrm{~s}, 3 \mathrm{H}), 1.08(\mathrm{~m}$,

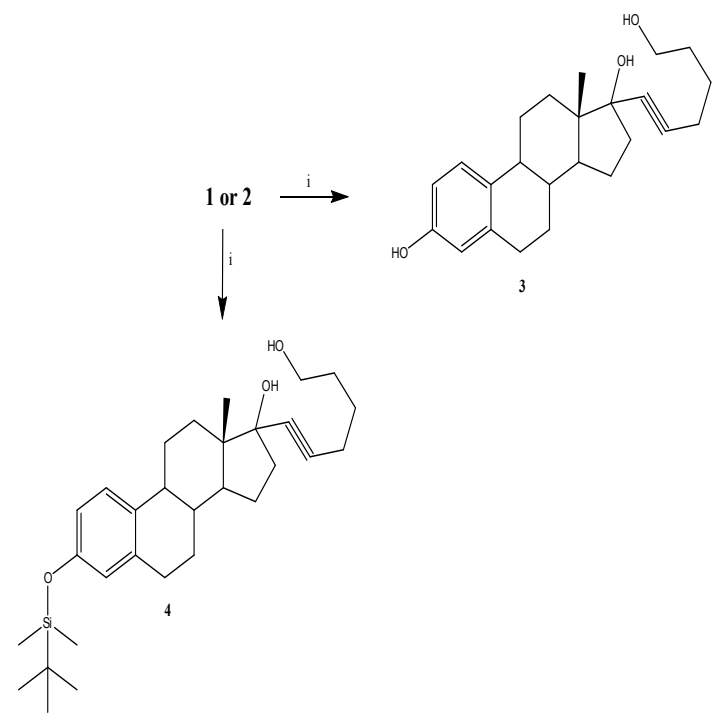

Scheme 2: Preparation of two propargyl alcohol derivatives (3 or 4). Reaction of estrone or OTBS-estrone with 5-Hexyn-1-ol. i = potassium hydroxide 
$2 \mathrm{H}), 1.22-1.64(\mathrm{~m}, 6 \mathrm{H}), 1.70(\mathrm{t}, 2 \mathrm{H}, \mathrm{J}=6.00 \mathrm{~Hz})$, 1.72-1.90 (m, 2H), 1.98 (t, 2H, J = 14.40 Hz), 2.00$2.24(\mathrm{~m}, 3 \mathrm{H}), 2.30(\mathrm{t}, 2 \mathrm{H}, \mathrm{J}=14.60 \mathrm{~Hz}), 2.34(\mathrm{~m}$, $1 \mathrm{H}), 2.40$ (t, $2 \mathrm{H}, \mathrm{J}=15.42 \mathrm{~Hz}), 2.68-2.76(\mathrm{~m}, 2 \mathrm{H})$, 2.96-3.02 (m, 4H), $3.12(\mathrm{~m}, 2 \mathrm{H}), 4.34(\mathrm{~m}, 4 \mathrm{H}), 5.96$ (broad, 2H), 6.70-7.28 (m, 3H) ppm. ${ }^{13} \mathrm{C}$ NMR $(75.4$ $\left.\mathrm{Hz}, \mathrm{CDCl}_{3}\right) \delta_{\mathrm{C}}: 11.80,19.34,23.34,24.00,25.44$, $25.50,27.70,27.74,28.00,29.70,30.00,31.78$, $33.70,35.22,37.38,44.89,45.20,47.45,50.85$, 53.57, 67.82, 80.00, 81.00, 81.62, 118.90, 120.84, $126.64,138.14,138.74,149.40$, 164.40, 169.16, 173.70, 177.52 ppm. El-MS m/z: 573.32 Anal. Calcd. for $\mathrm{C}_{34} \mathrm{H}_{43} \mathrm{~N}_{3} \mathrm{O}_{5}: \mathrm{C}, 71.18 ; \mathrm{H}, 7.55 ; \mathrm{N}, 7.32 ; \mathrm{O}, 13.94$. Found: $\quad$ C, 71.08; $\mathrm{H}, 7.48$.

(11Z,13'S)-3'-((tert-butyldimethylsilyl)oxy)$13^{\prime \prime}$ methyl-6 $6^{\prime}, 7^{\prime}, 8^{\prime}, 9^{\prime}, 11^{\prime}, 12^{\prime}, 13^{\prime}, 14^{\prime}, 15^{\prime}$, $16^{\prime}$ - d e c a h y d r o - 2, 10 - d i ox a - 12, 15 diazaspiro[bicycle[9.4.2] heptadecane-3,17'[cyclo- penta [a]phenanthrene]-1(15),11-dien-4yne (8)

yielding $55 \%$ of product, m.p. $134-136{ }^{\circ} \mathrm{C}$; IR $\left(\mathrm{V}_{\max }, \mathrm{cm}^{-1}\right): 3398$ and 2192; ${ }^{1} \mathrm{H}$ NMR $(300 \mathrm{MHz}$, $\left.\mathrm{CDCl}_{3}\right) \delta_{\mathrm{H}}: 0.28(\mathrm{~s}, 6 \mathrm{H}), 0.98(\mathrm{~s}, 3 \mathrm{H}), 1.04(\mathrm{~s}, 9 \mathrm{H})$, $1.08(\mathrm{~m}, 2 \mathrm{H}), 1.22-1.62(\mathrm{~m}, 6 \mathrm{H}), 1.70(\mathrm{t}, 2 \mathrm{H}, \mathrm{J}=6.45$ $\mathrm{Hz})$, 1.72-1.92 (m, 3H), $1.98(\mathrm{t}, 2 \mathrm{H}, \mathrm{J}=14.40 \mathrm{~Hz})$, 2.00-2.82 (m, 6H), 2.96-3.00 (m, 4H), $3.12(\mathrm{~m}, 2 \mathrm{H})$,

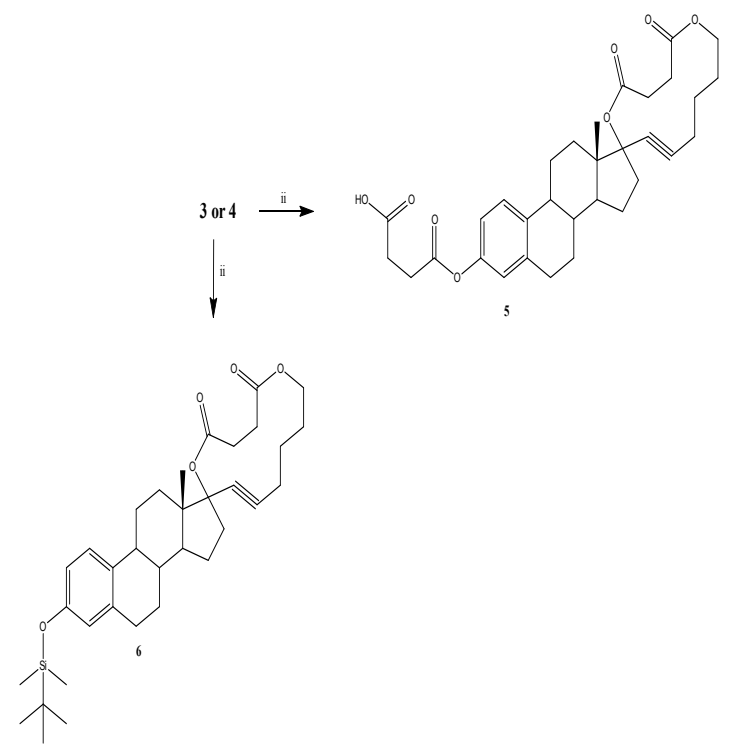

Scheme 3: Synthesis of two dioxaspirosteroid-cyclotridecan derivatives (5 or 6 ). Reaction of 3 or 4 with succinic acid. ii = 1,3Dicyclohexylcarbodiimide/ptoluensulfonic acid $4.34(\mathrm{~m}, 4 \mathrm{H}), 6.84-7.28(\mathrm{~m}, 3 \mathrm{H}) \mathrm{ppm} .{ }^{13} \mathrm{C}$ NMR $(75.4$ $\left.\mathrm{Hz}, \mathrm{CDCl}_{3}\right) \delta_{\mathrm{C}}:-4.44,11.80,18.16,19.36,23.32$, $24.00,25.42$, 25.50, 25.68, 27.70, 27.74, 28.00, $29.60,33.70,36.22,37.40,44.89,45.18,47.46$, $50.88,53.57,67.82,79.00,81.00,81.62,117.20$, 119.94, 126.14, 132.70, 137.74, 153.42, 164.42, $173.70 \mathrm{ppm}$. El-MS m/z: 588.37 Anal. Calcd. for $\mathrm{C}_{36} \mathrm{H}_{52} \mathrm{~N}_{2} \mathrm{O}$ Si: C, 73.42; $\mathrm{H}, 8.90 ; \mathrm{N}, 4.76 ; \mathrm{O}, 8.15$; Si, 4.77. Found: C, 73.34; H, 8.82.

\subsection{Removal of silyl fragment of $\mathbf{8}$ via hydrofluoric acid to form 9}

A solution of 8 (200 $\mathrm{mg} 0.34 \mathrm{mmol})$, in 5 $\mathrm{ml}$ hydrofluoric acid was stirring for $12 \mathrm{~h}$ to room temperature. The reaction mixture was evaporated to dryness under reduced pressure. After, the residue was purified by crystallization from methanol:water (3:2)

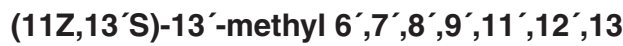
',14',15',16'-decahydro-2,10-dioxa-12,15diazaspiro[bicycle[9.4.2] heptadecane-3,17'[cyclopenta[a]phenanthrene]-1(15),11-dien-4yn-3'-ol (9). yielding $76 \%$ of product, m.p. $248-250{ }^{\circ} \mathrm{C}$; IR $\left(\mathrm{V}_{\max }, \mathrm{cm}^{-1}\right): 3398,3322,2192 ;{ }^{1} \mathrm{H}$ NMR (300 $\left.\mathrm{MHz}, \mathrm{CDCl}_{3}\right) \delta_{\mathrm{H}}: 0.98(\mathrm{~s}, 3 \mathrm{H}), 1.10(\mathrm{~m}, 2 \mathrm{H}), 1.22-$

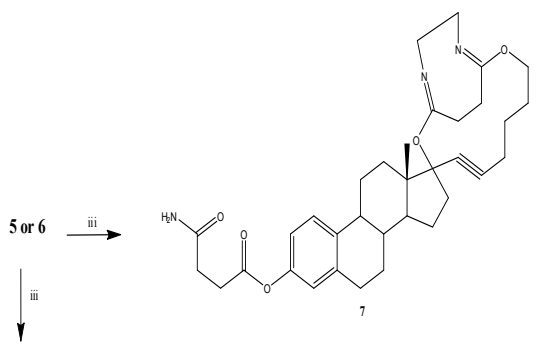

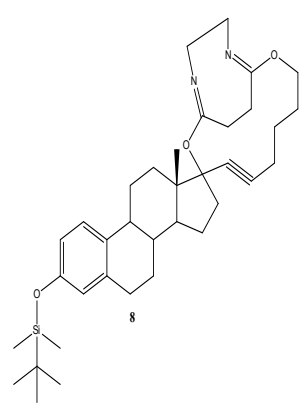

Scheme 4: Preparation of diazaspiro[bicycle[9.4.2] heptadecane-steroid-4 amino complex (7 or 8). Reaction of 5 or 6 with ethylenediamine to form 7 or $\mathbf{8}$ i = boric acid 
$1.62(\mathrm{~m}, 6 \mathrm{H}), 1.70(\mathrm{t}, 2 \mathrm{H}, \mathrm{J}=6.45 \mathrm{~Hz}), 1.72-1.92$ $(\mathrm{m}, 3 \mathrm{H}), 1.98(\mathrm{t}, 2 \mathrm{H}, \mathrm{J}=14.40 \mathrm{~Hz}), 2.00-2.76(\mathrm{~m}$, $6 \mathrm{H}), 2.96-3.00(\mathrm{~m}, 4 \mathrm{H}), 3.12(\mathrm{~m}, 2 \mathrm{H}), 4.34(\mathrm{~m}, 4 \mathrm{H})$, 6.74-7.28 (m, 3H) ppm 8.96 (broad, $1 \mathrm{H}) .{ }^{13} \mathrm{C}$ NMR $\left(75.4 \mathrm{~Hz}, \mathrm{CDCl}_{3}\right) \delta_{\mathrm{C}}: 11.80,19.36,23.32,24.00$, 25.42 , 25.50, 27.70, 27.74, 28.00, 30.26, 33.70, $35.22,37.40,44.89,45.18,47.46,50.88,53.57$, $67.82,79.00,81.00,81.62,113.32,115.64,126.94$ 132.30, 138.44, 153.22, 164.42, 173.70 ppm. El-MS $\mathrm{m} / \mathrm{z}: 474.28$ Anal. Calcd. for $\mathrm{C}_{30} \mathrm{H}_{38} \mathrm{~N}_{2} \mathrm{O}: \mathrm{C}, 75.92 ; \mathrm{H}$, 8.07; N, 5.90; O, 10.11. Found: C, 75.84; H, 8.00.

Preparation of diazaspiro[bicycle[9.4.2] heptadecane-steroid-4-oxobutanoic acid (10) via esterification of 9 .

A solution of 9 (200 $\mathrm{mg} 0.42 \mathrm{mmol})$, succinic acid $(100 \mathrm{mg}, 0.85 \mathrm{mmol}), 1,3-$ dicyclohexylcarbodiimide (120 $\mathrm{mg}, 0.58 \mathrm{mmol}$ ), p-toluensulfonic acid monohydrate $260 \mathrm{mg}$ (1.36 $\mathrm{mmol}$ ) in acetonitile:methanol $6 \mathrm{ml}$ (1:2) was stirring for $72 \mathrm{~h}$ to room temperature. The reaction mixture was evaporated to dryness under reduced pressure. After, the residue was purified by crystallization from methanol:water:hexane (3:1)

4-(((11Z,13'S)-13'-methyl-6 ',7',8 $8^{\prime}, 9^{\prime}, 11^{\prime}, 12^{\prime}$, $13^{\prime}, 14^{\prime}, 15^{\prime}, 16^{\prime}$-decahydro-2,10-dioxa-12, 15diazaspiro[bicycle[9.4.2] heptadecane-3,17'[cyclopenta[a]phenanthrene]-1(15),11-dien-4-yn3 '-yl)oxy)-4-oxobutanoic acid (10)

yielding $76 \%$ of product, m.p. $180-182{ }^{\circ} \mathrm{C}$; IR $\left(\mathrm{V}_{\text {max }}, \mathrm{cm}^{-1}\right): 3324,2192,1748$ and 1712; ${ }^{1} \mathrm{H} \mathrm{NMR}$ $\left(300 \mathrm{MHz}, \mathrm{CDCl}_{3}\right) \delta_{\mathrm{H}}: 0.98(\mathrm{~s}, 3 \mathrm{H}), 1.10(\mathrm{~m}, 2 \mathrm{H})$, 1.22-1.62 (m, 6H), $1.70(\mathrm{t}, 2 \mathrm{H}, \mathrm{J}=6.45 \mathrm{~Hz}), 1.72-$ $1.92(\mathrm{~m}, 3 \mathrm{H}), 1.98(\mathrm{t}, 2 \mathrm{H}, \mathrm{J}=14.40 \mathrm{~Hz}), 2.00-2.34$ $(\mathrm{m}, 4 \mathrm{H}), 2.60(\mathrm{~m}, 2 \mathrm{H}), 2.64-2.74(\mathrm{~m}, 2 \mathrm{H}), 2.90(\mathrm{~m}$, $2 \mathrm{H}), 2.96-3.00(\mathrm{~m}, 4 \mathrm{H}), 3.12(\mathrm{~m}, 2 \mathrm{H}), 4.34(\mathrm{~m}, 4 \mathrm{H})$, 6.74-7.28 (m, 3H) ppm 8.66 (broad, $1 \mathrm{H}) .{ }^{13} \mathrm{C}$ NMR $\left(75.4 \mathrm{~Hz}, \mathrm{CDCl}_{3}\right) \delta_{\mathrm{C}}: 11.80,19.36,23.32,24.00$, 25.42 , 25.50, 27.70, 27.74, 28.00, 29.32, 29.70, 29.74, 33.70, 35.22), 37.40, 44.89, 45.18, 47.46, $50.88,53.57,67.82,79.00,81.00,81.62,119.32$, 121.44, 126.64, 138.14, 138.76, 149.72, 164.42, 171.28, 173.70, 174.12 ppm. El-MS m/z: 574.30 Anal. Calcd. for $\mathrm{C}_{34} \mathrm{H}_{42} \mathrm{~N}_{2} \mathrm{O}_{6}: \mathrm{C}, 71.06 ; \mathrm{H}, 7.37 ; \mathrm{N}$, 4.87; O, 16.70. Found: C, 71.00; H, 7.24.

Amidation of $\mathbf{1 0}$ with ethylenediamine to form diazaspiro[bicycle[9.4.2] heptadecane-steroid4-aminobutanoate (7).

A solution of $10(200 \mathrm{mg} 0.35 \mathrm{mmol})$, ethylenediamine $(80 \mu \mathrm{l}, 0.74 \mathrm{mmol})$ boric acid (40 $\mathrm{mg}, 0.65 \mathrm{mmol}$ ) in $10 \mathrm{~mL}$ of methanol was stirring for $24 \mathrm{~h}$ at room temperature. The reaction mixture was evaporated to dryness under reduced pressure. After, the residue was purified by crystallization from methanol:water (3:2), yielding $67 \%$ of product. Similar ${ }^{1} \mathrm{H}$ NMR and ${ }^{13} \mathrm{C}$ NMR data were obtained compared with the reaction of $\mathbf{5}$ with ethylenediamine ethylenediamine to form 7.

\section{Reduction of amide group of 7 to form 11}

A solution of 7 (200 $\mathrm{mg} 0.34 \mathrm{mmol})$, $\mathrm{NaBH}_{3} \mathrm{CN}(30 \mathrm{mg}, 0.48 \mathrm{mmol}$ ) in $10 \mathrm{ml}$ of dioxane:water $(3: 2)$ was stirring for $72 \mathrm{~h}$ to room temperature. The reaction mixture was evaporated to dryness under reduced pressure. After, the residue was purified by crystallization from methanol:water $(4: 2)$.

( $\left.11 \mathrm{Z}, 13^{\circ} \mathrm{S}\right)-13^{\prime}-\mathrm{m}$ e t h y I $6^{\prime}, 7^{\prime}, 8^{\prime}, 9^{\prime}, 11^{\prime}, 12^{\prime}, 13^{\prime}, 14^{\prime}, 15^{\prime}, 16^{\prime}$-decahydro2,10-dioxa-12,15-diazaspiro [bicyclo[9.4.2] heptadecane-3,17 - c y c lopenta [a] phenantherene]1(15),11-dien-4-yn-3'-yl 4-aminobutanoate (11)

yielding $60 \%$ of product, m.p. $230-232{ }^{\circ} \mathrm{C}$; IR $\left(\mathrm{V}_{\max }, \mathrm{cm}^{-1}\right): 3322,2194$ and 1748; ${ }^{1} \mathrm{H}$ NMR (300 $\left.\mathrm{MHz}, \mathrm{CDCl}_{3}\right) \delta_{\mathrm{H}}: 0.98(\mathrm{~s}, 3 \mathrm{H}), 1.08(\mathrm{~m}, 2 \mathrm{H}), 1.22$ $1.54(\mathrm{~m}, 4 \mathrm{H}), 1.56(\mathrm{t}, 2 \mathrm{H}, \mathrm{J}=6.72 \mathrm{~Hz}), 1.60-1.63(\mathrm{~m}$, $2 \mathrm{H}), 1.70(\mathrm{t}, 2 \mathrm{H}, \mathrm{J}=6.00 \mathrm{~Hz}), 1.72-1.76(\mathrm{~m}, 2 \mathrm{H}), 1.84$ (broad, 2H), $1.90(\mathrm{~m}, 1 \mathrm{H}), 1.98(\mathrm{~m}, 2 \mathrm{H}), 2.00-2.34$ (m, 4H), $2.36(\mathrm{t}, 2 \mathrm{H}, \mathrm{J}=15.42 \mathrm{~Hz}), 2.66-2.77(\mathrm{~m}$, $2 \mathrm{H}), 2.80(\mathrm{~m}, 2 \mathrm{H}), 2.96-3.02(\mathrm{~m}, 4 \mathrm{H}), 3.12(\mathrm{~m}, 2 \mathrm{H})$, $4.34(\mathrm{~m}, 4 \mathrm{H}), 6.73-7.28(\mathrm{~m}, 3 \mathrm{H}) \mathrm{ppm} .{ }^{13} \mathrm{C}$ NMR $(75.4$ $\left.\mathrm{Hz}, \mathrm{CDCl}_{3}\right) \delta_{\mathrm{C}}: 11.80,19.34,23.34,24.00,25.44$, $25.50,26.32,27.70,27.74,28.00,29.70,30.80$, $33.70,35.22$, 37.38, 40.64, 44.89, 45.20, 47.45, 50.85, 53.57, 67.82, 79.00, 81.00, 81.62, 119.30, 121.24, 126.64, 138.14, 138.74, 148.80, 164.40, 168.64, 173.70 ppm. El-MS m/z: 559.34 Anal. Calcd. for $\mathrm{C}_{34} \mathrm{H}_{45} \mathrm{~N}_{3} \mathrm{O}_{4}: \mathrm{C}, 72.96 ; \mathrm{H}, 8.10 ; \mathrm{N}, 7.51 ; \mathrm{O}, 11.43$. Found: C, 72.88; H, 7.42.

Synthesis of dioxa-diazaspiro[bicyclo[9.4.2] hepta- decane-steroid-dienyne (12) via pyrrolization of 11 .

A solution of 11 (200 $\mathrm{mg} 0.38 \mathrm{mmol})$, ethylenediamine $(80 \mu \mathrm{l}, 0.74 \mathrm{mmol})$ boric acid (40 $\mathrm{mg}, 0.65 \mathrm{mmol}$ ) in $10 \mathrm{ml}$ of methanol was stirring for $72 \mathrm{~h}$ to room temperature. The reaction mixture was evaporated to dryness under reduced pressure. After, the residue was purified by crystallization from methanol:water (4:1) 
(11Z,13'S)-3'-((3,4-dihydro-2H-pyrrol-5-yl) oxy)-13'-methyl-6 $6^{\prime}, 7^{\prime}, 8^{\prime}, 9^{\prime}, 11^{\prime}, 12^{\prime}, 13^{\prime}, 14^{\prime}$, $15^{\prime}, 16^{\prime}$-decahydro-2,10-dioxa-12,15diazaspiro[bicyclo[9.4.2] heptadecane-3,17'cyclopenta[a]phenantherene]1(15),11-dien-4-yne (12)

yielding $52 \%$ of product, m.p. $158-160{ }^{\circ} \mathrm{C}$; IR $\left(\mathrm{V}_{\max }, \mathrm{Cm}^{-1}\right): 3324$ and 2192; ${ }^{1} \mathrm{H} \mathrm{NMR}(300 \mathrm{MHz}$, $\left.\mathrm{CDCl}_{3}\right) \delta_{\mathrm{H}}: 0.98(\mathrm{~s}, 3 \mathrm{H}), 1.08(\mathrm{~m}, 2 \mathrm{H}), 1.22-1.62(\mathrm{~m}$, $6 \mathrm{H}), 1.70(\mathrm{t}, 2 \mathrm{H}, \mathrm{J}=6.00 \mathrm{~Hz}), 1.72-1.90(\mathrm{~m}, 2 \mathrm{H}), 1.98$ $(\mathrm{m}, 2 \mathrm{H}), 2.00(\mathrm{~m}, 1 \mathrm{H}), 2.10-2.18(\mathrm{~m}, 2 \mathrm{H}), 2.24-2.76$ $(m, 4 H), 2.76(m, 1 H), 2.77(m, 1 H), 2.80(m, 1 H)$, $2.84(\mathrm{~m}, 1 \mathrm{H}), 2.96-3.02(\mathrm{~m}, 4 \mathrm{H}), 3.12(\mathrm{~m}, 2 \mathrm{H}), 4.14$ $-4.20(\mathrm{~m}, 2 \mathrm{H}), 4.34(\mathrm{~m}, 4 \mathrm{H}), 6.90-7.28(\mathrm{~m}, 3 \mathrm{H}) \mathrm{ppm}$. ${ }^{13} \mathrm{C}$ NMR $\left(75.4 \mathrm{~Hz}, \mathrm{CDCl}_{3}\right) \delta_{\mathrm{C}}: 15.82,19.34,20.50$, 23.34, 23.76, 25.44, 25.50, 27.58, 27.90, 28.00, $29.40,29.80,33.70,33.74,38.78,43.34,44.11$, $47.45,50.85,52.22,56.90,67.82,79.00,81.00$, $81.62,115.76,118.80,127.84,137.00,139.84$, 155.50, 164.40, 167.24, 173.70 ppm. El-MS m/z: 541.33 Anal. Calcd. for $\mathrm{C}_{34} \mathrm{H}_{43} \mathrm{~N}_{3} \mathrm{O}_{3}: \mathrm{C}, 75.38 ; \mathrm{H}, 8.00$; $\mathrm{N}, 7.76$; O, 8.86. Found: C, 75.26; H, 7.92.

\section{RESULTS AND DISSCUSION}

There are reports which indicate the preparation of diverse bicycle derivatives; nevertheless, expensive reagents and special conditions are required. Therefore, in this study a dioxa-diazaspiro[bicyclo[9.4.2] heptadecane-steroiddienyne derivative from estrone and OTBS-estrone was synthetized using several strategies.

\section{Propargylic-alcohols derivatives via reaction of terminal Alkynes with ketone group (3 or 4 )}

There are several reports which showed the preparation of some propargylic-alcohols using different methods and reagents such as disulfide-oxazolidine ${ }^{10}, \mathrm{Ti}(\mathrm{O}-\mathrm{i}-\mathrm{Pr})_{4}{ }^{-} \mathrm{BINOL}$ complex ${ }^{11}$, chiral diamine-coordinated tin(II) triflate ${ }^{12}$, $\mathrm{P}\left(\mathrm{PhCH}_{2} \mathrm{NCH}_{2} \mathrm{CH}_{2}\right)_{3} \mathrm{~N}^{13}$ and others; however some of these reagents are difficult to handle require and special conditions. Therefore, in this work the estrone was reacted with 5-Hexyn-1-ol in basic medium (Scheme 2). The mechanism of reaction involves a mechanism via $\mathrm{SN}_{2}$. The ${ }^{1} \mathrm{H}$ NMR spectrum of 3 showed several signals at $0.92 \mathrm{ppm}$ for methyl group; at 1.22-1.50, 1.70-2.10, 2.24-2.76 and 6.48$7.10 \mathrm{ppm}$ for steroid moiety; at 1.58-1.60, 2.20, and $3.66 \mathrm{ppm}$ for methylene groups involved in the arm bound to both D-ring of steroid and alkyne group; at $5.54 \mathrm{ppm}$ for hydroxyl groups. The ${ }^{13} \mathrm{C}$ NMR spectra displays chemical shifts at $12.128 \mathrm{ppm}$ for methyl group; at 18.90, 25.54, 31.82 and 62.12 for methylene groups involved in the arm bound to both D-ring of steroid and alkyne group; at 23.66, 26.92$30.30,34.90-52.80,80.10$ and $112.72-153.02$ ppm for steroid moiety; at 80.66-83.42 ppm for carbons of alkyne group. Finally, the presence of compound 3 was confirmed with mass spectrum which showed a molecular ion at 368.23.

On the other hand the ${ }^{1} \mathrm{H}$ NMR spectrum of 4 showed several signals at 0.28 and $1.04 \mathrm{ppm}$ for ter-buthyldimethylsylane fragment; at $0.92 \mathrm{ppm}$ for methyl group; at 1.22-1.50, 1.70-2.10, 2.24-2.82 and 6.84-7.28 ppm for steroid moiety; at 1.58-1.60, 2.20, and $3.66 \mathrm{ppm}$ for methylene groups involved in the arm bound to both $\mathrm{D}$-ring of steroid and alkyne group; at $3.84 \mathrm{ppm}$ for hydroxyl group. The ${ }^{13} \mathrm{C}$ NMR spectra displays chemical shifts at $-4.44,18.16$ and 25.70 ppm for carbos of ter-buthyldimethylsylane fragment; at $12.128 \mathrm{ppm}$ for methyl group; at 18.90, 25.54, 31.82 and $62.12 \mathrm{ppm}$ for methylene groups involved in the arm bound to both D-ring of steroid and alkyne group; at 23.66, 26.92-29.62, 34.90-52.80, 80.10 and 117.10-153.32 ppm for steroid moiety; at 80.6683.42 for carbons of alkyne group. Additionally, the presence of compound $\mathbf{4}$ was confirmed with mass spectrum which showed a molecular ion at 482.77 .

\section{Esterification 3 or 4 with succinic acid to form two dioxaspiro-steroid-cyclotridecan derivatives (5 or 6$)$}

There are diverse reagents used as catalyst to preparing of ester derivatives ${ }^{14,15}$; however, most of the conventional methods are of limited use for some compounds. Therefore, in this study the method reported by Erlanger and coworkers ${ }^{16}$ for esterification of other compounds was used. Thus, compounds 5 or 6 were prepared by the reaction of 3 or 4 with succinic acid using 1,3dicyclohexylcarbodiimide (DCC) as coupling reagent. It is important to mention that when DCC is used alone as a condensing agent in ester synthesis, the yield of esters is often unsatisfactory due to formation of an $\mathrm{N}$-acylurea by-product. Some reports showed that addition of a catalytic amount of a strong acid to the esterification reaction in the presence of DCC considerably increases the yield of esters and 
decreases the formation of $\mathrm{N}$-acylurea ${ }^{3}$. Therefore, $\mathrm{p}$-toluenesulfonic acid was used to increase the yield of 5 or 6 in the esterification of 3 or 4 with succinic acid in the presence of DCC (Scheme 3). The ${ }^{1} \mathrm{H}$ NMR spectrum of 5 showed several signals at 0.98 ppm for methyl group; at 1,08, 1.50, 2.24 and 4.10 ppm for methylene groups bound to both alkyne and ester groups; at 2.54-2.58 ppm for methylene groups bound to both ester groups; at 1.22-1.44, 1.58-2.22, 2.38-2.46, 2.68-2.76 and 6.78-7.28 ppm for steroid moiety; at 2.60-2.90 ppm for methylene groups bound to ester an carboxyl groups; at $8.70 \mathrm{ppm}$ for carboxyl group. The ${ }^{13} \mathrm{C}$ NMR spectra displays chemical shifts at 10.90 for methyl group; at 19.20, $28.60,32.10$ and $64.82 \mathrm{ppm}$ for methylene bound to both ester and alkyne groups; at 30.00-31.72 ppm for methylene groups bound to both ester groups; at 23.64-28.70, 29.70, 34.32-52.80, 80.99 and 119.50149.80 ppm for steroid moiety; at 29.30 and 29.74 ppm for methylene groups bound to both ester and carboxyl groups; at 79.10 and 89.02 ppm for alkyne group; at 171.30-173.70 ppm for carbons of ester groups; at $174.12 \mathrm{ppm}$ for carboxyl group. Finally, the presence of compound $\mathbf{5}$ was confirmed with mass spectrum which showed a molecular ion at 550.25.

On the other hand, the ${ }^{1} \mathrm{H}$ NMR spectrum of 6 showed several signals at 0.28 and $1.10 \mathrm{ppm}$ for tert-buthyldimethylsylane fragment; at $0.98 \mathrm{ppm}$ for methyl group; at 1,08, 1.50, 2.24 and $4.10 \mathrm{ppm}$ for methylene groups bound to both alkyne and ester groups; at 2.54-2.58 ppm for methylene groups bound to both ester groups; at 1.22-1.44, 1.58-2.22, 2.38-2.46, 2.80-2.82 and 6.84-7.28 ppm for steroid moiety; at 2.54-2.58 ppm for methylene groups bound to ester an carboxyl groups. The ${ }^{13} \mathrm{C}$ NMR spectra displays chemical shifts at $-4.44,18.16$ and $25.72 \mathrm{ppm}$ for tert-buthyldimethylsylane fragment; at 10.90 for methyl group; at 19.20, 28.60, 32.10 and $64.82 \mathrm{ppm}$ for methylene bound to both ester and alkyne groups; at 30.00-31.72 ppm for methylene groups bound to both ester groups; at 23.66, 26.7427.70, 29.60, 34.32-52.80, 80.99 and 117.20-153.42 ppm for steroid moiety; at 79.10 and 89.02 ppm for alkyne group; at 172.04-173.70 ppm for carbons of ester groups. In addition, the presence of compound 6 was confirmed with mass spectrum which showed a molecular ion at 564.32 .
Preparation of diazaspiro[bicycle [9.4.2] heptadecane-steroid-4 amino complex (7 or 8).

There are several methods for preparation of ether derivatives which involve the use of different reagents such hexyl bromide/sodium cyanide17, m-chloroperoxybenzoic $\mathrm{acid}^{18}$, hydrazonyl chloride ${ }^{19}$, $\mathrm{N}, \mathrm{N}$-dimethylbarbituric $\mathrm{acid}^{20}$ and others. In this study, the compounds 7 or 8 were prepared via formation of imino group from 5 or 6 with ethylenediamine in presence of boric acid (Scheme 4). It is also noteworthy, that dditionally compound 7 involves the formation of an amide group participating in the arm attached to A-ring of steroid. The ${ }^{1} \mathrm{H}$ NMR spectrum of 7 showed several signals at $0.98 \mathrm{ppm}$ for methyl group; at 1,08, 1.70, 1.98 and $3.12 \mathrm{ppm}$ for methylene groups bound to both alkyne and ester groups; at 1.22-1.64, 1.72-1.90, 2.00-2.24, 2.34, 2.68-2.76 and 6.70-7.28 ppm for steroid moiety; at $2.30-2.40 \mathrm{ppm}$ for methylene groups bound to ester an carboxyl groups; at 2.96-3.02 and 4.34 ppm for methylene groups bound to imino groups; at $5.96 \mathrm{ppm}$ for carboxyl group. The ${ }^{13} \mathrm{C}$ NMR spectra displays chemical shifts at 11.80 for methyl group; at 19.34, 25.44-25.50 and $67.82 \mathrm{ppm}$ for methylene bound to both ester and alkyne groups; at 23.34, 28.00, 47.45-50.85 ppm for methylene groups bound to imino groups; at 24.00, 27.70-27.74, 29.70, $33.70-45.20,53.57,80.00$ and $118.90-149.40 \mathrm{ppm}$ for steroid moiety; at 30.00-31.78 ppm for methylene groups bound to both ester and carboxyl groups; at 81.00 and $86.62 \mathrm{ppm}$ for alkyne group; at 164.40 and $173.70 \mathrm{ppm}$ for imino groups; at $169.16 \mathrm{ppm}$ for ester group; at $177.52 \mathrm{ppm}$ for carboxyl group. Finally, the presence of compound $\mathbf{7}$ was confirmed with mass spectrum which showed a molecular ion at 573.32 .

On the other hand, the ${ }^{1} \mathrm{H}$ NMR spectrum of 8 showed several signals at 0.28 and $1.04 \mathrm{ppm}$ for tert-buthyldimethylsylane fragment; at $0.98 \mathrm{ppm}$ for methyl group; at 1.08, 1.70, 1.98 and $3.12 \mathrm{ppm}$ for methylene groups bound to both alkyne and ester groups; at 1.22-1.62, 1.72-1.92, 2.00- 2.82 and 6.84$7.28 \mathrm{ppm}$ for steroid moiety; at $2.96-3.00$ and 4.34 $\mathrm{ppm}$ for methylene groups bound to imino groups. The ${ }^{13} \mathrm{C}$ NMR spectra displays chemical shifts at -4.44 , 18.16 and $25.68 \mathrm{ppm}$ for tert-buthyldimethylsylane fragment; at $11.80 \mathrm{ppm}$ for methyl group; at 19.36, 28.42-25.50 and $67.82 \mathrm{ppm}$ for methylene bound to 
both ester and alkyne groups; at 23.34, 28.00, 47.4550.85 ppm for methylene groups bound to imino groups; at 24.00, 27.70-27.740, 29.60-45.18, 53.57, 79.00 and 117.20-153.42 ppm for steroid moiety; at 81.00-81.62 ppm for alkyne group; at 164.42-173.70 ppm for imino groups. In addition, the presence of compound $\mathbf{8}$ was confirmed with mass spectrum which showed a molecular ion at 588.37.

Removal of silyl fragment of $\mathbf{8}$ via hydrofluoric acid to form 9

There are several reagent for removal of silyl protecting groups from hydroxyl such as ammonium fluoride 21,20 , tris(dimethylamino) sulfonium/difluorotrimethylsilicate ${ }^{22}$, hydrofluoric

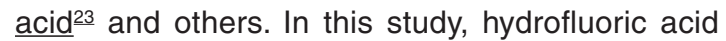
was used to removal of silyl-protecting group from hydroxyl of the compound 8 to form 9 (Scheme 5). The ${ }^{1} \mathrm{H}$ NMR spectrum of 9 showed several signals at $0.98 \mathrm{ppm}$ for methyl group; at 1.10, 1.70, 1.98 and $3.12 \mathrm{ppm}$ for methylene groups bound to both alkyne and ester groups; at 1.22-1.62, 1.72-1.92, 2.00- 2.76and 6.74-7.28 ppm for steroid moiety; at 2.96-3.00 and $4.34 \mathrm{ppm}$ for methylene groups

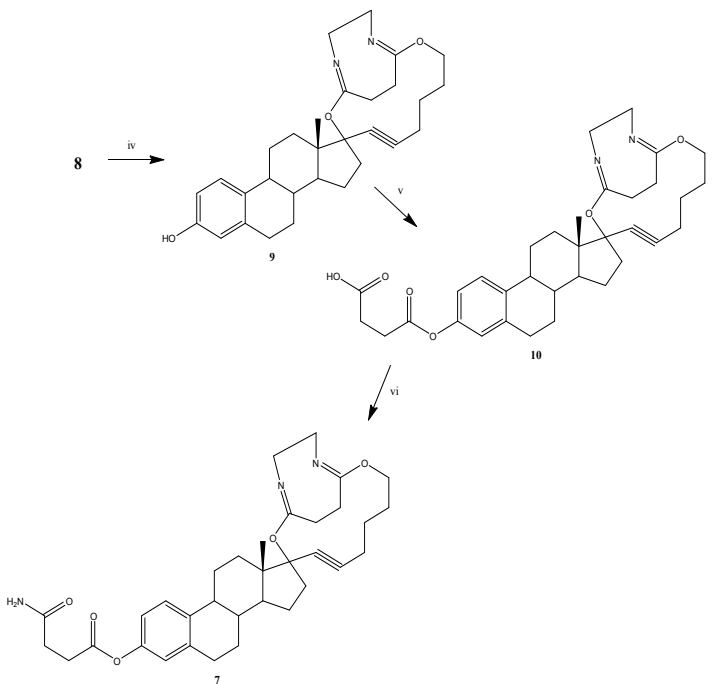

Scheme 5: Synthesis of diazaspiro[bicyclo[9.4.2] heptadecane-steroid-4-aminobutanoate (7). Reaction of 8 with hydrofluoric acid to form diazaspiro[bicycle[9.4.2] heptadecane-3steroiddien-yn-3'-ol (9). Then 9 was reacted with succinic acid (v) to form the diazaspiro[bicycle[9.4.2] heptadecane-steroid-4-oxobutanoic acid (10). Finally, 7 was prepared by the reaction of 10 with ethylenediamine (vi). bound to imino groups at 8.96 for hydroxyl group. The ${ }^{13} \mathrm{C}$ NMR spectra displays chemical shifts at 11.80 ppm for methyl group; at 19.36, 25.42-25.50 and $67.82 \mathrm{ppm}$ for methylene bound to both ester and alkyne groups; at 23.34, 28.00, 47.45-50.85 ppm for methylene groups bound to imino groups; 24.00 , 27.70-27.74, 30.26-45.18, 53.57, 79.00 and 113.32153.22 ppm for steroid moiety; at 81.00-81.62 ppm for alkyne group; at 164.42-173.70 ppm for imino groups. In addition, the presence of compound 9 was confirmed with mass spectrum which showed a molecular ion at 474.28 .

Preparation of diazaspiro[bicycle[9.4.2] heptadecane-steroid-4-oxobutanoic acid (10) via esterification of $\mathbf{9}$

The compound 10 was prepared by the reaction of 9 with succinic acid using 1,3-dicyclohexylcarbodiimide in presence of p-toluenesulfonic acid (Scheme 5). The ${ }^{1} \mathrm{H}$ NMR spectrum of 10 showed several signals at $0.98 \mathrm{ppm}$ for methyl group; at 1.10, 1.70, 1.98 and 3.12 ppm for methylene groups bound to both alkyne and ester groups; at 1.22-1.62, 1.72-1.92, 2.00-2.34 and 6.74-7.28 ppm for steroid moiety; at 2.60, 2.90 ppm for methylene groups bound to both ester and

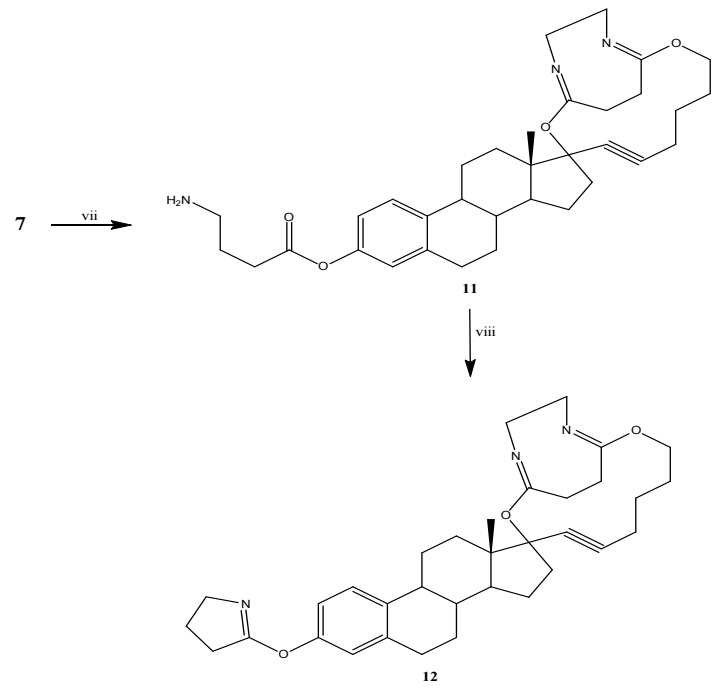

Scheme 6: Synthesis of dioxadiazaspiro[bicyclo[9.4.2]heptadecane-steroiddienyne (12). Reaction of 7 with $\mathrm{NaBH} 3 \mathrm{CN}$ to form the compound diazaspiro[bicyclo[9.4.2] heptadecane-steroid 4-aminobutanoate derivative (11). Following, 11 was reacted with ethylenediamine/boric acid to form 12 
carboxyl groups; at 2.96-3.00 and $4.34 \mathrm{ppm}$ for methylene groups bound to imino groups at $8.96 \mathrm{ppm}$ for hydroxyl group; at 8.66 ppm for carboxyl group. The ${ }^{13} \mathrm{C}$ NMR spectra displays chemical shifts at 11.80 ppm for methyl group; at 19.36, 25.42-25.50 and $67.82 \mathrm{ppm}$ for methylene bound to both ester and alkyne groups; at 23.30, 28.00, 47.46-50.88 ppm for methylene groups bound to imino groups; 24.00, 27.70-27.74, 29.70, 33.70-45.18, 53.57, 79.00 and $119.32-149.72$ ppm for steroid moiety; at 81.00-81.62 ppm for alkyne group; at 164.42-173.70 ppm for imino groups; at 171.28 ppm for ester group at $174.12 \mathrm{ppm}$ for carboxyl group. In addition, the presence of compound 10 was confirmed with mass spectrum which showed a molecular ion at 574.30.

\section{Amidation of 10 with ethylenediamine to form diazaspiro[bicyclo[9.4.2] heptadecane-steroid- 4-aminobutanoate (7) \\ Many procedures for the formation of amide} groups are known in the literature, the most widely practiced method employs carboxylic acid chlorides as the electrophiles which react with the amine in the presence of an acid scavenger ${ }^{24}$. Despite its wide scope, this protocol suffers from several drawbacks; most notable are the limited stability of many acid chlorides and the need for hazardous reagents for their preparation (thionyl chloride) ${ }^{25}$. In this work two different methods for amide formation were employed, in the first one the technique reported by Pingwah ${ }^{26}$ for boric acid catalyzed amidation of carboxylic acids and amine was used. Therefore, boric acid was used as catalyst in the reaction of 10 with ethylenediamine to form the compounds 7 (Scheme 5). Here, is important to mention that with this method, the yield of 7 was higher compared to the reaction of $\mathbf{5}$ with ethylenediamine.

\section{Reduction of amide group of 7 to form 11}

Several reagents have been used for reduction of amides to form amino groups such as $\mathrm{Fe}_{3}(\mathrm{CO})_{12}{ }^{27}$, $\mathrm{LiAlH}^{28}$, borohydride derivative ${ }^{29}$ and others. In this study, 7 was reacted with $\mathrm{NaBH}_{3} \mathrm{CN}$ to form 11. The ${ }^{1} \mathrm{H}$ NMR spectrum of 11 showed several signals at $0.98 \mathrm{ppm}$ for methyl group; at $1,08,1.70,1.98$ and 3.12 ppm for methylene groups bound to both alkyne and ester groups; at 1.22-1.54, $1.60-1.63,1.72-1.76,1.90,2.00-2.34,2.66-2.77$ and 6.73-7.28 ppm for steroid moiety; at 1.56, 2.36 and $2.80 \mathrm{ppm}$ for methylene groups bound to ester and amino groups; at 1.84 for amino group; at 2.96-3.02 and $4.34 \mathrm{ppm}$ for methylene groups bound to imino groups. The ${ }^{13} \mathrm{C}$ NMR spectra displays

chemical shifts at 11.80 for methyl group; at 19.34, 25.44-25.50 and67.82 ppm for methylene bound to both ester and alkyne groups; at 23.34, $28.00,47.45-50.85 \mathrm{ppm}$ for methylene groups bound to imino groups; at 24.00, 27.70-27.74, 29.70, 33.70$37.38,44.89-45.20,53.57,79.00$ and 119.30-148.80 ppm for steroid moiety; at 26.32, 30.80 and 40.64 ppm for methylene groups bound to both ester and amino groups; at 81.00 and 86.62 ppm for alkyne group; at 164.40 and 173.70 ppm for imino groups; at $168.64 \mathrm{ppm}$ for ester group. Finally, the presence of compound 11 was confirmed with mass spectrum which showed a molecular ion at 559.34.

\section{Synthesis of dioxa-diazaspiro[bicyclo[9.4.2] hepta- decane-steroid-dienyne (12) via pyrrolization of 11}

There are different methods for the preparation of pyrrole derivatives ${ }^{30-33}$; nevertheless, some protocols that require hazardous reagents as well as different experimental conditions for the preparation of these compounds. In this study 11 was reacted with ethylenediamine in presence of boric acid to form an imino group and consequently bring formation of the pyrrole ring involved in the compound 12 (Scheme 6). The ${ }^{1} \mathrm{H}$ NMR spectrum of 12 showed several signals at $0.98 \mathrm{ppm}$ for methyl group; at 1.08, 1.70, 1.98 and 3.12 ppm for methylene groups bound to both alkyne and ester groups; at 1.22-1.62, 1.72-1.90, 2.00, 2.24-2.76, 2.80 and 6.907.28 ppm for steroid moiety; at 2.10-2.18, 2.77, 2.84 and 4.14-4.20 ppm for pyrrole ring; at 2.96-3.02 ppm for methylene groups bound to imino groups. The ${ }^{13} \mathrm{C}$ NMR spectra displays chemical shifts at 15.82 for methyl group; at 19.34, 25.44-25.50 and 67.82 ppm for methylene bound to both ester and alkyne groups; at 23.34, 28.00, 47.45-50.85 ppm for methylene groups bound to imino groups; at 23.76, 25.58-27.90, 33.70-44.11, 52.22, 79.00 and 115.76-155.50 ppm for steroid moiety; at 26.32, 30.80 and 40.64 ppm for methylene groups bound to both ester and amino groups; at 81.00 and 86.62 ppm for alkyne group; at 164.40 and 173.70 ppm for imino groups. Finally, the presence of compound 12 was confirmed with mass spectrum which showed a molecular ion at 541.33. 


\section{CONCLUSIONS}

In this study is reported a straightforward route for synthesis of a dioxa-diazaspiro [bicyclo[9.4.2] heptadecane-steroid-dienyne derivative using some strategies. The proposed methods offer some advantages such as simple procedure, low cost, and ease of workup.

\section{REFERENCES}

1. Kaszynski, P.; Michl, J. J. Org. Chem. 1988, 53, 4593-4594.

2. Nicolaou, K.; Pfefferkorn, J.; Guo, C.; Kim, S.; Kessabi, J. Org. Lett. 1999, 1, 807-810.

3. Hernandez, A.; Rapoport, M. J. Org. Chem. 1995, 60, 2683-2691.

4. Subba, B.; Venkateswarlu, A.; Borkar, P.; Yadav, J.; Kanakaraju, M.; Kunwar, A.; Sridhar, A. J. Org. Chem. 2013, 78, 6303-6308.

5. Subba, B.; Borkar, P.; Chakravarthy, P.; Yadav, J.; Gree, R. Tetrahedron Lett. 2010, 51, 34123416.

6. Rueping, M..; Kuenkel, A.; Fröhlich, R. Chem. Eur. J. 2010, 16, 4173-4176.

7. Rigby, J.; Sage, J. J. Org. Chem. 1983, 48, 3591-3592.

8. Harding, K.; Trotter, J.; May, L. J. Org. Chem. 1977, 42, 2715-2719.

9. Figueroa-Valverde, L.; Díaz-Cedillo, F.; RosasNexticapa, M.; Hau-Heredia, L.; GarcíaCervera, E.; Pool-Gómez, E.; Sarabia-Alcocer, B. J. Chem. In line, 2014, Article ID 460968, http://dx.doi.org/10.1155/2014/460968

10. Braga, L.; Appelt, H.; Silveira, C.;Wessjohannb, L.; Schneider, P. Tetrahedron. 2002, 58, 10413-10416.

11. Marshall, J.; Bourbeau, M. Org. Lett. 2003 5, 3197-3199.

12. Mukaiyama, T.; Furuya, M.; Ohtsubo, A.; Kobayashi, S. Chem. Lett. 1991, 20, 989992.

13. Wadhwa, K.; Chintareddy, V.; Verkade, J. J. Org. Chem. 2009, 74, 6681-6690.

14. Nahar, L.; Turner, A. Steroids. 2003, 68, 11571161.

15. Medvedeva, M.; Safronova, A.; Sarapulova, G. Arkivoc. 2001, ix, 143-149.

16. Erlanger, B.; Borek, F.; Beiser, S.; Lieberman,
S. J. Biol. Chem. 1959, 234, 1090-1094.

17. Benfenati, E.; Fanelli, R.; Bosone, E.; Biffi, C.; Caponi, R.; Cianetti, M.; Farina, P. Drug Metab. Dispos. 1991, 19, 913-916.

18. Yates, P.; Hoare, J. Canadian J. Chem. 1983, 61, 1397-1404.

19. Farag, A.; Korany, E. J. Heteroc. Chem. 2008, 45 279-283.

20. Islam, M.; Barakat, A.; Al-Majid, A.; Ghabbour, H.; Fun, H.; Rafiq, M. Arabian J. Chem. 2015, online, doi:10.1016/j.arabjc.2015.03.007

21. Zhang, W.; Robins, M. Tetrahedron Lett. 1992, 33, 1177-1180.

22. Scheidt, K.; Chen, H.; Follows, B.; Chemler, S.; Coffey, D.; Roush, W. J. Org. Chem. 1998, 63, 6436-6437.

23. Newton, R.; Reynolds, D.; Finch, M.; Kelly, D.; Roberts, S. 1979, 20, 3981-3982.

24. Armstrong, S.; Bertozzi, J. Org. Lett. 2000, 2, 2141-2143.

25. Taddei, M. Org. Lett. 1999, 1, 1355-1357.

26. Figueroa-Valverde, L.; Díaz-Cedillo, F.; Ceballos-Reyes, G. J. Mex. Chem. Soc. 2006, 50, 42-45.

27. Zhou, S.; Junge, K.; Addis, D.; Das, S.; Beller, M. Agew. Chem. 2009, 121, 9671-9674.

28. Douat, C.; Heitz, A.; Martinez, J.; Fehrentz, J. Tetrahedron Lett. 2000, 41, 37-40.

29. Satoh, T.; Suzuki, S. Tetrahedron Lett. 1969, 4555-4558.

30. Schley, N.; Dobereiner, E.; Crabtree, H. Organometallics. 2011, 30, 4174-4179.

31. Zhang, M.; Neumann, H.; Beller, M. Angew. Chem. 2013, 125, 625-6.29.

32. Kanchithalaivan, S.; Kumar, R.; Perumal, S. Steroids. 2013, 78, 409-417.

33. Crawley, M.; Goljer, I.; Jenkins, D.; Mehlmann, J.; Nogle, L.; Dooley, R.; Mahaney, P. Org. Lett. 2006, 8, 5837-5840. 